\title{
Congenital dyserythropoietic anemia
}

INSERM

\section{Source}

INSERM. (1999). Orphanet: an online rare disease and orphan drug data base. Congenital dyserythropoietic anemia. ORPHA:85

Congenital dyserythropoietic anemia (CDA) is a heterogenous group of hematological disorders of late erythropoiesis and red cell abnormalities that lead to anemia. Five types of CDA are defined: CDA I, CDA II, CDA III, CDA IV and thrombocytopenia with CDA (see these terms). 